\title{
症例報告
}

\section{膵癌切除例における遅発性孤立性肺転移の臨床病理組織学的特徵と 化学療法の意義}

\author{
新潟大学大学院医歯学総合研究科消化器 - 一般外科学分野, 新潟労災病院外科* \\ 高野 可赴 黒崎 功 皆川 昌広 \\ 北見 智恵 伊達 和俊* 畠山 勝義
}

\begin{abstract}
脺癌の 3 大再発様式は肝転移, 局所再発, 腹膜播種であるが, 肺転移の臨床的特徵や治療に ついては明らかではない. 免疫組織学的に証明された孤立性肺転移 4 例の臨床病理学的特徵と gemcitabine + TS-1 併用療法（以下，GS 療法）の意義について検討を加えた４例とも初回膵 切除後に gemcitabine が投与されていた. 術後無再発生存期間は 26〜 78 か月であった. 単発病 変の 2 例は原発性肺癌, 多発性の 2 例は転移が疑われ肺切除が施行された. 全例において病理 組織学的, 免疫組織学的に肺転移と診断された. 術後 1 例を除き GS 療法が行われた. 肺切除後 の転帰は 2 例がおのおの 36,14 か月生存中で， 2 例がおのおの 32,14 か月に再発にて死亡し た. 膵癌治癒切除後の孤立性肺転移は比較的遅発性であり, 肺切除後の化学療法により比較的 長い生存期間が得られた. 他の腹腔内再発様式と比較して生物学的悪性度が低い可能性が示唆 された。
\end{abstract}

\section{はじめに}

膵癌は治癒切除後も高率に腹腔内諸臟器に再発 を来すが, 孤立性肺転移についてはその転移経路 や病理組織学的特徵が十分に解明されていない. 膵癌の遠隔転移に対する治療は gemcitabine（以 下, GEM)による化学療法 ${ }^{1)}$ や, 近年は GEM + TS1 併用療法（以下, GS 療法）の比較的良好な成績 が報告され23), 化学療法の有用性が指摘されてい る. 膵癌治癒切除後の孤立性肺転移 4 切除例を経 験したので文献的考察を加え報告する.

\section{症例}

4 例の平均年齢は 68 歳で全例女性であった (Table 1)。病変は体部 3 例, 頭部 1 例で, 閉塞性 黄疸は 1 例で認められた。術前に肺疾患の既往は 認められなかった。原発巣の膵切除は全胃温存膵 頭十二指腸切除が 2 例, 膵体尾部切除が 2 例に施 行され, 1 例で No. 16a2 lateroに 1 個のリンパ節 転移が認められた. 切除断端は全例除性であった.

$<2010$ 年 5 月 19 日受理 $>$ 別刷請求先 : 高野 可赴 T951-8510 新潟市中央区旭町通 1 番町 757 新潟大 学大学院医歯学総合研究科消化器 - 一般外科学分野
初回術後の補助化学療法は, GEM 単独（GEM $1,000 \mathrm{mg} / \mathrm{m}^{2}, 3$ 週投与 1 週休薬) が 3 例, $5-\mathrm{FU}$ の肝動注門注による肝潅流化学療法 (肝動注 5-FU $125 \mathrm{mg} /$ day, 門注 5-FU $125 \mathrm{mg} /$ day, 28 日間）+ GEM (GEM 1,000mg $/ \mathrm{m}^{2}$, 隔週投与)が 1 例であっ た. GEM の投与期間は 1 例が 6 か月（11 回），ほ か 3 例は 19〜21 か月（31～41 回）であった.

術後は 3〜4 か月間隔で CT が施行され, 全例再 発は術後 2 年以上経過後に胸部 high resolution CT (以下, HRCT) にて肺腫瘤が指摘された. HRCT 上, 肺腫瘤は単発が 2 例, 多発が 2 例（お のおの 2 個) であった (Table 2). 単発の 2 例（症 例 1，4）では原発性肺癌が疑われ，ほか 2 例（症 例 2，3）では 2 個の孤立性肺転移が疑われた。手 術適応として，(1)耐術性があること，(2)膵癌術後 腹腔内の原発巣がコントロールされていること,

(3)肺以外に転移がないこと, (4)肺病巣の個数が少 なく,すべて切除可能なことが挙げられ, 以上を 全例満たしており肺切除が行われた. しかし, 単 発例のうち 1 例 (症例 4) は, 開胸時に 8 個の転移 巣が判明した。すべて切除されたが, 胸腔内洗浄 
Table 1 First operation and perioperative demographic data of the 4 patients

\begin{tabular}{c|c|c|c|c|c|c|c|c|c|c}
\hline Case & Age & Gender & $\begin{array}{c}\text { Tumor } \\
\text { location }\end{array}$ & $\begin{array}{c}\text { Type of } \\
\text { surgery }\end{array}$ & $\begin{array}{c}\text { Histologic } \\
\text { grade }\end{array}$ & S & RP & TN & Stage & $\begin{array}{c}\text { Adjuvant } \\
\text { chemotherapy (mo) }\end{array}$ \\
\hline 1 & 68 & Female & $\mathrm{Pb}$ & $\mathrm{DP}$ & Mod & $(+)$ & $(-)$ & T3N0 & III & GEM (21) \\
2 & 78 & Female & $\mathrm{Pb}$ & $\mathrm{PPPD}$ & Well & $(+)$ & $(+)$ & T3N0 & III & GEM (6) \\
3 & 69 & Female & $\mathrm{Ph}$ & $\mathrm{PPPD}$ & Well & $(-)$ & $(+)$ & T3N2 & IVa & LPC $*$ GEM $(20)$ \\
4 & 77 & Female & $\mathrm{Pb}$ & $\mathrm{DP}$ & Mod & $(-)$ & $(+)$ & T4N3** & IVb & GEM (19) \\
\hline
\end{tabular}

$\mathrm{Ph}$, pancreatic head ; $\mathrm{Pb}$, pancreatic body ; PPPD, pylorus-preserving pancreaticoduodenectomy ; DP, distal pancreatectomy ; Well, Mod, well, moderately differentiated adenocarcinoma ; GEM, gemcitabine

* liver perfusion chemotherapy with 5 -fluorouracil via hepatic artery and portal vein

** No. 16 a2 latero lymph node metastasis

Table 2 Clinical characteristics of 4 patients with isolated lung metastases from pancreatic cancer

\begin{tabular}{|c|c|c|c|c|c|c|}
\hline Case & $\begin{array}{l}\text { DFS } \\
(\mathrm{mo})\end{array}$ & $\begin{array}{l}\text { Number of } \\
\text { lung nodule (size) }\end{array}$ & $\begin{array}{l}\text { Type of } \\
\text { surgery }\end{array}$ & Chemotherapy & $\begin{array}{l}\text { Site of } \\
\text { re-recurrence }\end{array}$ & $\begin{array}{l}\text { Prognosis } \\
\left(\mathrm{mo}^{*}\right)\end{array}$ \\
\hline 1 & 37 & $1(8 \mathrm{~mm})$ & lobectomy \# & GEM + TS-1 & Lung & Alive (36) \\
\hline 2 & 31 & $2(15,13 \mathrm{~mm})$ & partial $^{\# \#}$ & $(-)$ & $(-)$ & Alive (14) \\
\hline 3 & 26 & $2(4,6 \mathrm{~mm})$ & partial \#\# & GEM + TS-1 & Peritoneum & DOD (32) \\
\hline 4 & 78 & $1 * *(20 \mathrm{~mm})$ & partial $^{\# \#}$ & GEM + TS-1 & Lung & DOD (14) \\
\hline
\end{tabular}

DFS, disease free survival (duration of diagnosis of lung metastases by CT) ; GEM, gemcitabine ; DOD, dead of disease

* survival after resection of lung metastases

** we detected 8 small lung metastases at operation whereas we diagnosed a single nodule by CT before surgery

\# right middle lobectomy of the lung

\# \# partial resection of the lung

細胞診陽性で姑息的手術となった.

術後の病理組織学的検索では, 原発巣と転移巣 における組織像の類似性と Thyroid transcription factor-1（以下, TTF-1）の陰性所見により, 全例 膵癌の肺転移と診断された（Fig. 1).

肺切除後は化学療法を拒否した 1 例 (症例 2) を 除き, 3 例で GS 療法 (TS-1, $40 \mathrm{mg} / \mathrm{m}^{2} /$ day : day $1 \sim 14$, GEM, $1,000 \mathrm{mg} / \mathrm{m}^{2}:$ day8, 15) が投与さ れた. しかし, 症例 4 では TS-1 の内服が早期に困 難となり GEM 単独療法に移行した. 化学療法の 副作用は症例 1, 3 において Grade 3 の好中球減 少がみられ, 休薬および GEM の減量（実投与量 $\left.800 \mathrm{mg} / \mathrm{m}^{2}\right)$ により GS 療法は継続可能であった.

また，Grade 4 以上の重篤な副作用は認められず 肺切除後おのおの 36,24 か月投与可能であった. 症例 3 は併存疾患として慢性心不全, 心房細動が あり，GS 療法投与 12 か月後に心房細動，心不全 症状が一時重篤化 (NYHA 分類 IV 度) して化学療 法は中止となった。 心電図異常は初回術前から認 められており, 化学療法と心疾患との関連は否定
的であった．心不全症状軽快後に GS 療法を再開 したが，原病の悪化とともに心不全症状が再増悪 し, 肺切除後 26 か月目で化学療法は中止となっ た.

肺切除後の転帰は, 2 例がおのおの 36,14 か月 生存中で, 2 例がおのおの 32,14 か月に再発死し た. 症例について詳述すると, 症例 1 は肺切除後 3 か月後の HRCT にて右 $\mathrm{S} 10$ に $6 \mathrm{~mm}$ 大の肺腫瘤 が指摘され転移と考えられた。しかし, 化学療法 の継続にて腫瘤増大なく肺切除後 36 か月生存中 である (Fig. 2)。腫瘍マーカーCEA は肺再発時 $6.3 \mathrm{ng} / \mathrm{ml}$, 肺再々発時は $5.8 \mathrm{ng} / \mathrm{ml}$ と軽度高值であ り, 肺切除後 19 か月目に $11.0 \mathrm{ng} / \mathrm{ml}$ と上昇した が, その後肺切除後 31 か月では $4.8 \mathrm{ng} / \mathrm{ml}$ と低下 した. CT 上腫瘤は 33 か月にわたり不変であり肺 切除後の long stable disease の症例であった。症 例 2 は左右おのおの 1 個の肺転移切除後, 未治療 であるものの 14 か月無再発生存中である. 症例 3 は上述したように心不全治療のため化学療法を 6 か月休薬したが, 肺切除後全経過 32 か月中 24 か 
Fig. 1 Microscopic findings of case 1

a : Microscopic findings of the resected pancreatic cancer showed well differentiated adenocarcinoma (H.E. $\times 200)$.

$\mathrm{b}$ : Microscopic findings of the resected lung tumor showed well differentiated adenocarcinoma (H.E. $\times 200$ ). Lung tumor resembled primary tumor in microscopic histological pattern.

c : Immunohistochemical staining showed thyroid transcription factor-1 was negative for lung tumor $(\times 200)$.
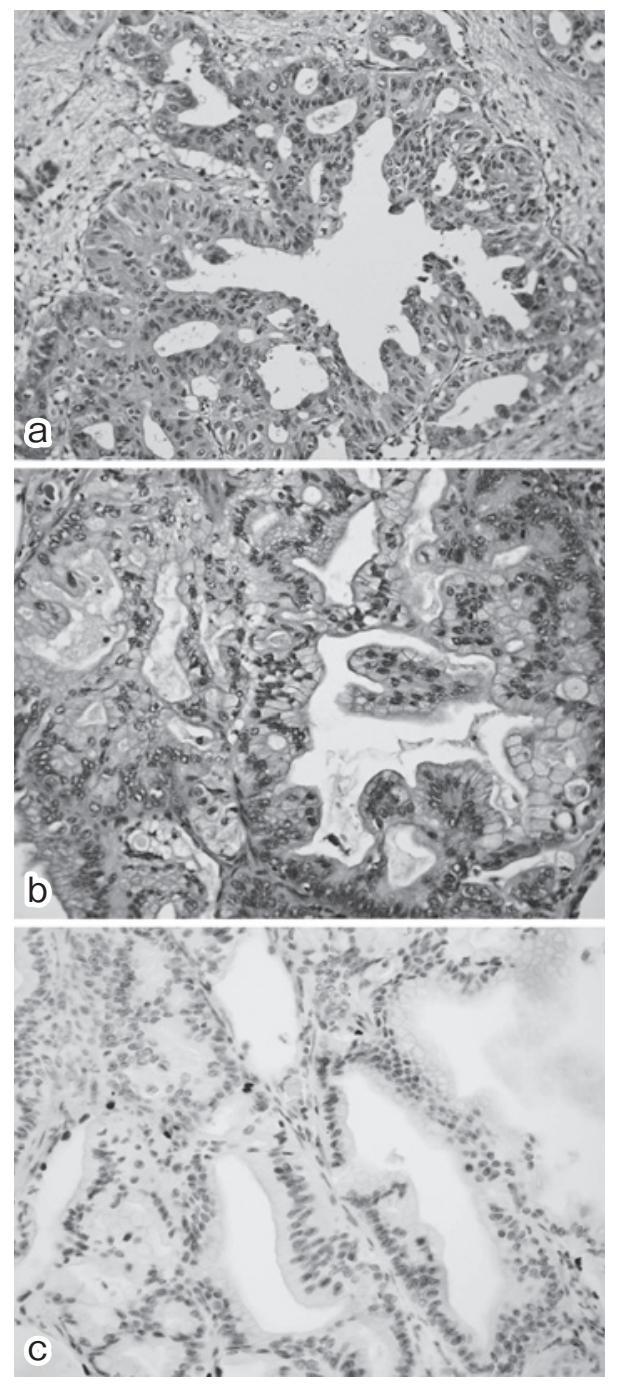

月の間 $\mathrm{GS}$ 療法が施行された. 肺切除後 20 か月後 に腹膜再発を来し 32 か月で死亡したが，肺への 再々発は最後まで認められなかった，症例 4 は肺
切除後 8 か月後に腹腔内再発は認められなかった ものの肺再発再増悪を来し 14 か月で死亡した.

\section{考察}

膵癌治癒切除後の腹腔内 3 大再発は肝転移, 腹 膜播種，局所再発である．特に，肝再発は比較的 早期に再発し予後に強い影響を与える( ${ }^{4) ~}$. し，肺再発の再発までの期間は 17.8 か月と肝再発 の 8.2 か月に比較して遅発性であることが報告さ れている6

本邦における膵癌術後における肺転移切除例の 報告は，医学中央雑誌で 1983 年〜2009 年の期間 において「膵癌術後」,「肺転移」,「肺切除」をキー ワードとして検索するかぎり 6 例の報告があった $(\text { Table } 3)^{7) \sim 11}$. Disease free survival (以下, DFS) は, 5 例では $3 \sim 9$ 年であり 1 年以内の肺再発例は 1 例のみであった．自験例では 4 例中 3 例は DFS が 26〜37 か月と 1 年以内の再発はみられず， 1 例は DFS 78 か月と 5 年生存後の再発であった. 膵癌術後における肺再発例の全体像を検討する必 要があるが，孤立性の肺転移は比較的遅発性に再 発する傾向があると思われた。しかし，何故孤立 性肺転移が腹腔内再発に比較して遅発性であるか は不明であり，非常に興味深いことである，孤立 性肺転移を来す膵癌は，もともと slow growing な発育を示す生物学的に比較的悪性度が低い癌の 可能性や, 抗癌剤に高い感受性を示す癌の可能性 がある。

一方，肺への転移経路であるが，膵臓は門脈系 臓器であり, 肝転移が最も頻度の高い転移臟器で ある。しかし，膵後方組織への浸潤やリンパ節転 移を来した症例では，直接大循環に入る経路も考 えられる. Cascade 理論 ${ }^{12} に$ に従わず肝臓をスキッ プする経路も否定できないと考えられる．自験の 4 例は, 膵後方組織への浸潤陽性が 3 例, 膵前方組 織への浸潤陽性 2 例であり膵内に限局した癌の例 はなく, また 2 群リンパ節転移陽性 1 例, 3 群リン パ節転移陽性 1 例と 2 例にリンパ節転移が見られ た。したがって，肺転移の経路は系門脈経路だけ でなく，直接大循環経路へ流入する経路も否定は できないと思われた。

膵癌術後補助化学療法に関する無作為化臨床比 
Fig. 2 Clinical course of Case 1

A : Thoracic high resolution CT (HRCT) showed a irregular nodule about $8 \mathrm{~mm}$ in diameter in the segment 4 of the right lung (arrow).

B : After lung resection, thoracic HRCT showed a small metastatic nodule in the segment 10 of the right lung (arrow head).

$\mathrm{C}$ : Last thoracic HRCT showed that a small metastatic nodule is detectable in the segment 10 of the right lung (arrow head).

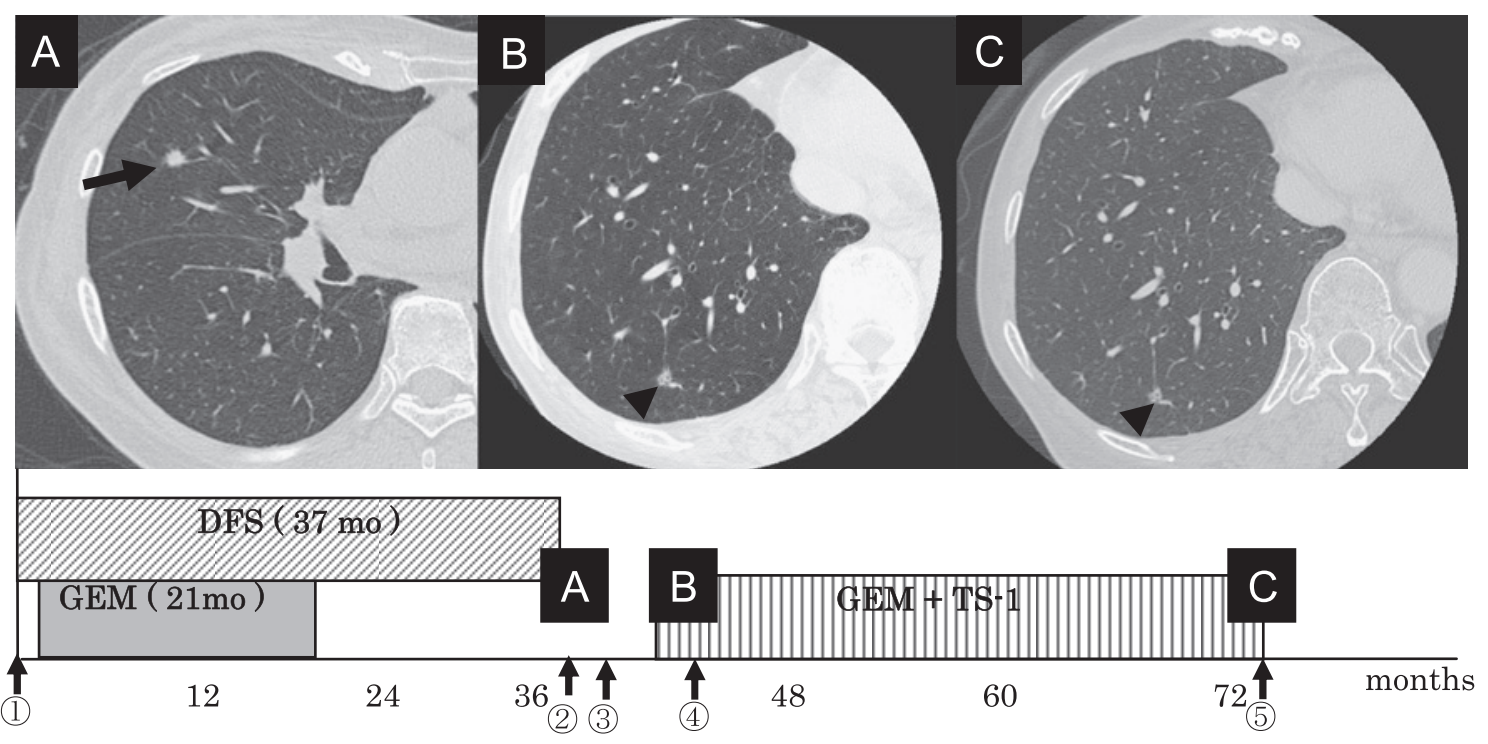

(1) first operation (2) lung recurrence (3) resection of lung metastasis (4) lung re-recurrence (5) Alive

Table 3 Reported cases of resection of isolated lung metastases from pancreatic cacncer

\begin{tabular}{l|c|c|c|c|c|c|c}
\hline \multicolumn{1}{c|}{ Author (Year) } & $\begin{array}{c}\text { Type of } \\
\text { surgery }\end{array}$ & Stage & $\begin{array}{c}\text { DFS } \\
(\mathrm{mo})\end{array}$ & $\begin{array}{c}\text { Number of lung } \\
\text { nodule }\end{array}$ & $\begin{array}{c}\text { Chemotherapy after } \\
\text { lung resection }\end{array}$ & $\begin{array}{c}\text { Site of } \\
\text { re-recurrence }\end{array}$ & $\begin{array}{c}\text { Prognosis } \\
(\text { mo* }\end{array}$ \\
\hline Ito $^{7)}(2003)$ & TP & IVa & 108 & 4 & n.d. & $(-)$ & Alive (11) \\
Sakurai $^{8}(2004)$ & PPPD & II & 60 & 1 & n.d. & $(-)$ & Alive $(4)$ \\
Shimada $^{9)}(2004)$ & PD & IVb & 60 & 1 & n.d. & $(-)$ & Alive $(24)$ \\
Enomoto $^{10)}(2008)$ & PD & I & 8 & 1 & n.d. & Alive $(6)$ \\
Hoda $^{11)}(2009)$ & DP & II & 48 & 2 & GEM & Lung, Peritoneum & DOD (37) \\
Hoda $^{11)}(2009)$ & PPPD & IVa & 36 & 1 & n.d. & $(-)$ & Alive $(6)$ \\
\hline
\end{tabular}

DFS, disease free survival (duration of diagnosis of lung metastases by CT) ; n.d., not discribed ; PPPD, pylorus-preserving pancreaticoduodenectomy; DP, distal pancreatectomy; TP, total pancreatectomy; GEM, gemcitabine ; DOD, dead of disease

* survival after resection of lung metastases

較試験のうち, Oettel らによるCONKO-001によ り GEM 投与の有用性が示され ${ }^{13)}$, GEM が膵癌術 後補助化学療法の第一選択薬と位置づけられてい る. 同試験では GEM の投与期間は 6 か月間で あったが，自験 4 例の初回術後の GEM の投与期 間は 1 例が 6 か月（11回），他の 3 例が 19 21 か月（31〜41 回）であった。膵癌術後補助化学療
法における GEM の投与期間について, 無作為比 較試験による報告はなく，適切な GEM の投与期 間については今後の課題と考えられた.

膵癌の遠隔転移に対し切除が行われることは極 めてまれである。自験例のうち，肺切除後 2 例は 肺の再々発を来したが，2 例では肺の再々発は認 められなかった．本邦の膵癌術後肺転移切除の報 
告 6 例中, 肺切除後の生存期間は 2 年以上が 2 例 に過ぎない.したがって，肺切除が予後の経過に 寄与しているかは疑問であり今後の検討を要す る. 膵癌の転移巣に対する切除について Shrikhande $ら^{14)}$ の検討では, 肝転移, 腹膜播種の切除後 の median survival time はおのおの 11.4, 12.9 か 月と報告している。現状では転移巣切除の意義は 十分には見出されず，手術適応は症例ごとに慎重 に検討すべきである。しかし，転移巣切除により 病理組織学的診断を行うことが可能となり, 適正 な化学療法を選択できる意義は大きいと思われ る。

原発性肺癌か転移性肺腫瘍かの鑑別には, 免疫 染色検查による TTF-1 の有用性が報告されてい $る^{15)}$. 本邦の報告例 6 例中, TTF-1 の陰性例は 4 例であった。自験例は原発巣との組織像の類似性 に加え, 全例 TTF-1 陰性であり免疫組織学的に肺 転移と診断された。

本邦の報告例のうち, 肺切除後の化学療法の記 載は 1 例のみでほかは記載されていない. 自験例 は化学療法を拒否した 1 例を除く 3 例に肺切除後 GS 療法が行われた. 症例 1 は肺切除後 3 か月後に 肺再々発が認められたが化学療法の継続にて腫瘤 の増大なく肺切除後 36 か月生存中であり, 化学療 法の効果は long stable disease と考えられた。 症 例 3 においては肺切除後の DFS は 20 か月であ り，化学療法の効果があったと思われたが，肺切 除後 32 か月後に腹膜再発にて死亡した. 症例 3 においては心不全症状増悪により化学療法の継続 が困難であったことも腹膜再発の一因と思われ た. TS-1の心毒性の報告は見られないが，5fluorouracil の心毒性は 1.6\% 18\% と報告され ており ${ }^{16)}$, 虚血性心疾患の頻度が最も高く, 投与 5 日以内の発症が多いと報告されている ${ }^{17}$. GEM の心毒性の報告は心房細動の報告が 3 例と極めて まれである.いずれも GEM 投与 24 時間以内に心 房細動の発症を繰り返すことが報告されてい $3^{1819)}$. しかし, 症例 3 の心不全症状増悪, 心房作 動発症前 2 週間以内に GEM, TS-1 は投与されて おらず副作用は否定的であった。

孤立性肺転移は他の再発様式と比較して遅発性
に発現し，かつ転移確認後の生存期間も長い傾向 にある。これは原発巣の生物学的悪性度が比較的 低いことに加え, 抗癌剤に感受性が高いことを示 している可能性がある。 その生物学的特性や転移 経路は未解明だが, 術後遠隔期においても注意深 い観察が必要であり，かつ孤立性の肺転移に対し ては, 症例によっては積極的な切除と化学療法は 予後を改善している可能性もあると思われた。膵 癌術後の厳重な経過観察と積極的な集学的治療は 意義があると思われた。

\section{文献}

1) Burris HA 3rd, Moore MJ, Andersen J et al : Improvements in survival and clinical benefit with gemcitabine as first-line therapy for patients with advanced pancreas cancer : a randomized trial. J Clin Oncol 15 : 2403-2413, 1997

2) Nakamura $K$, Yamaguchi $T$, Ishihara $T$ et al : Phase II trial of oral S-1 combined with gemcitabine in metastatic pancreatic cancer. Br J Cancer $5: 1575-1579,2006$

3) Saif MW : Is there a standard of care for the management of advanced pancreatic cancer? Highlights from the Gastrointestinal Cancers Symposium. Orlando, FL, USA. January 25-27, 2008. JOP 8 : 91-98, 2008

4) Takamori H, Hiraoka T, Kanemitsu K et al : Identification of prognostic factors associated with early mortality after surgical resection for pancreatic cancer-under-analysis of cumulative survival curve. World J Surg $30: 213-218,2006$

5) Takamori H, Hiraoka $T$, Kanemitsu $K$ et al : Long-term outcomes of extended radical resection combined with intraoperative radiation therapy for pancreatic cancer. J Hepatobiliary Pancreat Surg $15: 603-607,2008$

6) Van den Broeck A, Sergeant G, Ectors N et al : Patterns of recurrence after curative resection of pancreatic ductal adenocarcinoma. Eur J Surg Oncol $35: 600-604,2009$

7）伊藤 博, 木村文夫, 清水宏明ほか：進行膵癌術 後 9 年で生じた両側肺転移の 1 切除例. 日臨外会 誌 $64: 1366$ - 1369,2003

8）櫻井裕幸, 羽田真朗, 小山敏雄ほか：膵癌手術 5 年後に孤立性肺転移を認めた 1 症例. 山梨肺癌研 会誌 $17: 102-106,2004$

9）島田順一, 伊藤和弘, 西村元宏ほか：孤立性結節 性膵癌肺転移の一切除例。日呼外会誌 19 : $581-584,2004$

10）榎本 豊, 齋藤祐二, 谷村繁雄ほか：術中穿刺細 胞診が有用であった膵臟癌孤立性肺転移の一切 除例. 日呼外会誌 23:75-80,2009 
11）保田紘一郎, 片岡正文, 仁熊健文ほか：膵癌肺転 移の 2 切除例. 日臨外会誌 $70: 691-696,2009$

12) Weiss L, Voit A, Lane WW : Metastatic patterns in patients with carcinomas of the lower esophagus and upper rectum. Invasion Metastasis 4 : 47-60, 1984

13) Oettle H, Post S, Neuhaus P et al : Adjuvant chemotherapy with gemcitabine vs observation in patients undergoing curative-intent resection of pancreatic cancer : a randomized controlled trial. JAMA 17 : 267-277, 2007

14) Shrikhande SV, Kleeff J, Reiser $C$ et al : Pancreatic resection for $\mathrm{M} 1$ pancreatic ductal adenocarcinoma. Ann Surg Oncol 14 : 118-127, 2007

15) Nakamura N, Miyagi E, Murata $S$ et al : Expression of thyroid transcription factor-1 in normal and neoplastic lung tissues. Mod Pathol 15 :
1058-1067, 2002

16) Labianca R, Beretta G, Clerici $M$ et al : Cardiac toxicity of 5-fluorouracil : A study on 1083 patients. Tumori $68: 505-510,1982$

17) Meydan N, Kundak I, Yavuzsen $T$ et al : Cardiotoxicity of de Gramont's regimen : incidence, clinical characteristics and long-term follow-up. Jpn J Clin Oncol 35 : 265-270, 2005

18) Santini D, Tonini G, Abbate A et al : Gemcitabine-induced atrial fibrillation : a hitherto unreported manifestation of drug toxicity. Ann Oncol 11: 479-481, 2000

19) Ferrari D, Carbone C, Codeca $\mathrm{C}$ et al : Gemcitabine and atrial fibrillation : a rare manifestation of chemotherapy toxicity. Anticancer Drugs $17: 359-361,2006$

\title{
Clinicopathological Features of Delayed Isolated Lung Metastases after Radical Pancreatectomy for Pancreatic Cancer
}

\author{
Kabuto Takano, Isao Kurosaki, Masahiro Minagawa, \\ Chie Kitami, Kazutoshi Date* and Katsuyoshi Hatakeyama \\ Division of Digestive and General Surgery, Niigata University \\ Graduate School of Medical and Dental Sciences \\ Department of Surgery, Niigata Rosai Hospital*
}

Clinical characteristics and the treatment of the lung metastases from pancreatic cancer have not been fully investigated. We report clinical features of 4 cases with isolated lung metastases that had been proven by immunohistochemical method and examined the efficacy of chemotherapy. Four cases received gemcitabine chemotherapy after primary pancreatectomy. Thoracic high resolution CT detected lung nodules in all cases. Disease free survival was 26-78 months. All cases received resection of lung nodule ; 2 cases with single nodule were diagnosed as primary lung cancer and another 2 cases with two nodules were diagnosed as lung metastases. In all cases, pathological and immunohistochemical examination revealed lung metastasis from pancreatic cancer. All but one patient received combination with gemcitabine and TS- 1 chemotherapy after lung resection. Two cases died of relapse at 32, 14 months after lung resection, while another 2 cases are alive at 36 , 14 months. Isolated lung metastasis after radical surgery for pancreatic cancer showed delayed recurrence and low malignant potential. Long survival term was obtained by chemotherapy after lung resection. It is suggested that close follow-up after pancreatectomy and effective chemotherapy seem to be essential for improving the prognosis of the lung recurrence.

Key words : pancreatic cancer, isolated lung metastases, chemotherapy

〔Jpn J Gastroenterol Surg 43 : 1270-1275, 2010]

\author{
Reprint requests : Kabuto Takano Division of Digestive and General Surgery, Niigata University Graduate \\ School of Medical and Dental Sciences \\ 1-757 Asahimachi-dori, Chuo-ku, Niigata, 951-8510 JAPAN
}

Accepted : May 19, 2010 